\title{
Efektivitas Ekstrak Etanol Daun Durian (Durio zibethinus (Linn.)) sebagai Antihiperurisemia
}

\author{
The Effectivity of Ethanol Extracts of Durio zibethinus (Linn.) Leaves \\ as Antihyperuricemia
}

\author{
Rela Sonia ${ }^{1}$ Yusnelti ${ }^{2}$, Fitrianingsih $^{1 *}$ \\ ${ }^{.}$Program Studi Farmasi, Fakultas Sains dan Teknologi, Universitas Jambi, Jambi, Indonesia \\ ${ }^{2}$ Program Studi Pendidikan Kimia, Fakultas Keguruan dan Ilmu Pendidikan, Universitas Jambi, Jambi, Indonesia \\ *E-mail: fitrianingsih@unja.ac.id
}

Diterima: 29 Agustus 2019

Direvisi:31 Januari 2020

Disetujui: 20 Juli 2020

\begin{abstract}
Abstrak
Daun durian (Durio zibethinus (Linn.)) diketahui mampu menghambat kerja dari enzim xantin oksidase yang dapat mengurangi pembentukan asam urat dalam darah. Penelitian ini bertujuan untuk mengetahui efektivitas ekstrak etanol daun durian dalam menurunkan kadar asam urat pada mencit yang dibuat hiperurisemia dengan diinduksi jus hati ayam $0,2 \mathrm{~mL} / 20 \mathrm{gBB}$ dan kalium oksonat $250 \mathrm{mg} / \mathrm{kgBB}$. Mencit yang digunakan adalah mencit dengan kadar asam urat di atas $3,3 \mathrm{mg} / \mathrm{dL}$ atau $6,2-7,1 \mathrm{mg} / \mathrm{dL}$. Rancangan penelitian yang digunakan adalah rancangan acak lengkap dengan 6 perlakuan dan 3 kali ulangan, masing-masing ulangan terdiri dari 3 mencit. Kelompok perlakuan adalah $\mathrm{K}+=$ Allopurinol $10 \mathrm{mg} / \mathrm{kgBB} ; \mathrm{K}-=\mathrm{CMC}-\mathrm{Na} 0,5 \%$; $\mathrm{P} 1=$ ekstrak 50 $\mathrm{mg} / \mathrm{kgBB}$; P2= ekstrak $100 \mathrm{mg} / \mathrm{kgBB}$; P3= ekstrak $200 \mathrm{mg} / \mathrm{kgBB} ; \mathrm{P} 4=$ ekstrak $250 \mathrm{mg} / \mathrm{kgBB}$. Pengukuran kadar asam urat dilakukan pada $\mathrm{H}-0$ dan $\mathrm{H}-6$ setelah induksi diet tinggi asam urat, serta $\mathrm{H}-15$ setelah pemberian perlakuan masing-masing kelompok. Data dianalisis dengan uji One Way Anova dan uji lanjut Post Hoc Duncan. Hasil penelitian menunjukkan bahwa ekstrak etanol daun durian mampu menurunkan kadar asam urat di dalam darah mencit dengan persentase penurunan tertinggi terdapat pada kelompok P2 (100 mg/kgBB) sebesar 40,53\%, diikuti dengan P1 (50 mg/kgBB) sebesar 38,68\%. Persentase penurunan kadar asam urat terendah terdapat pada kelompok P4 (250 mg/kgBB) sebesar 22,36\%, diikuti dengan kelompok P3 (200 $\mathrm{mg} / \mathrm{kgBB}$ ) sebesar $27,71 \%$ dan nilai $\mathrm{ED}_{50}$ terdapat pada dosis $61,65 \mathrm{mg} / \mathrm{KgBB}$. Ekstrak etanol daun durian berpengaruh secara signifikan terhadap penurunan kadar asam urat total pada mencit dan memiliki potensi sebagai obat antihiperurisemia.
\end{abstract}

Kata kunci: Antihiperurisemia; Ekstrak etanol daun durian; In vivo

\begin{abstract}
Durian (Durio zibethinus Linn.) leaves are known to inhibit the xanthine oxidase enzyme which can reduce uric acid levels in the blood. The purpose of study is to determine the effectiveness of ethanol extracts of durian leaves in reducing uric acid levels in hyperuricemic mice. The mice were induced with chicken's liver juice 0,2 $\mathrm{mL} / 20 \mathrm{gBW}$ and potassium oxonate $250 \mathrm{mg} / \mathrm{kgBW}$. The animals were mice with uric acid levels above $3,3 \mathrm{mg} / \mathrm{dL}$ or 6,2-7,1 mg/dL. The study was used a completely randomized design (CRD) with six treatments and three replications, with three mice in each replications. The treatments group were $\mathrm{K+}$ : Allopurinol $10 \mathrm{mg} / \mathrm{kgBW}$; $\mathrm{K}-$ : CMC-Na 0.5\%; extracts in group P1,P2, P3, P4 are 50; 100; 200; $250 \mathrm{mg} / \mathrm{kgBW}$. The measurements of uric acid levels were performed on day-0, day-6 after induction, and day-15 after administering each group. The data obtained were analyzed by One Way Anova test followed by Duncan's Post Hoc further test. The results showed that durian leaves could reduce uric acid levels in mice blood with the highest percentage reduction was in P2 (100 mg/kgBW) group of 40,53\%, followed by P1 (50 mg/kgBW) of 38,68\%. The lowest percentage was in the P4 group $(250 \mathrm{mg} / \mathrm{kgBW})$ of 22,36\%, followed by the P3 group (200 $\mathrm{mg} / \mathrm{kgBW})$ of $27,71 \%$ and the ED 50 value was $61,65 \mathrm{mg} / \mathrm{kgBW}$. In conclusion, ethanol extracts of durian leaves has a significant effect on decreasing total uric acid levels in mice and has potential as an antihyperuricemia agent.
\end{abstract}

Keywords: Antihyperuricemia; Ethanol extracts of durian leaves; In vivo 


\section{PENDAHULUAN}

Perkembangan zaman yang terjadi pada saat ini dapat menyebabkan berbagai perubahan dalam kehidupan. Salah satu dampak pada kesehatan yaitu pola makan yang tidak sehat dengan kandungan purin yang tinggi serta kurang olahraga sehingga menyebabkan berbagai gangguan kesehatan seperti obesitas, peningkatan kolesterol, dan asam urat. Asam urat merupakan produk akhir dari degradasi purin dalam darah yang tidak mempunyai fungsi secara fisiologis. Asam urat dalam darah pada kondisi normal yaitu 3,4-7,0 $\mathrm{mg} / \mathrm{dL}$ pada laki-laki dan 2,4-5,7 $\mathrm{mg} / \mathrm{dL}$ pada wanita. Asam urat pada keadaan normal dapat memiliki fungsi yang baik bagi tubuh yaitu sebagai antioksidan. Hiperurisemia adalah suatu keadaan yang ditandai dengan adanya peningkatan kadar asam urat di dalam darah yang melebihi batas normal yaitu pada laki-laki di atas $7,0 \mathrm{mg} / \mathrm{dL}$ dan wanita di atas $6,0 \mathrm{mg} / \mathrm{dL}$. Prevalensi hiperurisemia di seluruh dunia mengalami peningkatan. Berdasarkan data Global Burden of Diseases (GBD) menunjukkan prevalensi hiperurisemia di Indonesia sebesar $18 \%$. $^{1,2,3}$

Hiperurisemia dapat diobati dengan pemberian obat yang dapat menurunkan kadar asam urat dan menghambat pembentukan asam urat dalam tubuh seperti penggunaan obat sintetis allopurinol yang menghambat xantin oksidase. Penggunaan allopurinol dalam jangka panjang cenderung menimbulkan efek samping seperti mual, muntah, diare, neuritis perifer, anemia aplastika, dan meningkatkan frekuensi serangan gout akut dengan inisiasi terapi. ${ }^{4,5}$ Oleh karena itu, diperlukan obat dari bahan alam yang dapat menurunkan kadar asam urat dengan efek samping yang relatif kecil dibandingkan dengan obat sintetis, selain itu juga dapat digunakan sebagai senyawa penuntun untuk menemukan obat baru.

Masyarakat memanfaatkan bagian dari daun durian untuk pengobatan karena memiliki aktivitas sebagai penurun demam, antifungi pada genus candida, gangguan pernafasan, dan penyembuhan luka. Daun durian juga memiliki khasiat sebagai antibakteri dan anestesi. ${ }^{6,7}$

Daun durian mempunyai senyawa metabolit sekunder antara lain alkaloid, flavonoid, saponin, glikosida, tanin, dan steroid/triterpenoid. Senyawa yang dapat berpotensi sebagai antihiperurisemia adalah flavonoid dan fenolik. Flavonoid memiliki aktivitas antiradikal bebas melalui penekanan radikal bebas Reactive Oxygen Species (ROS), yaitu dengan cara penghambatan kerja enzim/kerusakan sel atau pengkhelatan ion logam yang terdapat dalam produksi radikal bebas. Flavonoid mampu menurunkan kadar asam urat dengan cara mencegah pembentukan radikal bebas. Senyawa fenolik juga diduga memiliki aktivitas sebagai antihiperurisemia karena mampu menghambat kerja dari enzim xantin oksidase. $^{8,9,10}$ Xantin oksidase merupakan enzim kunci pada manusia, terutama pada metabolisme purin dengan bertindak sebagai katalis reaksi hidroksilasi oksidatif hipoxantin menjadi xantin dan hasil selanjutnya adalah pembentukan asam urat. ${ }^{11}$ Jalur ini merupakan jalur degradasi purin dengan penurunan $\mathrm{O}_{2}$ di pusat flavin dan menghasilkan Reactive Oxygen Species (ROS), baik radikal anion superoksida atau hidrogen peroksida. ${ }^{12}$

Penelitian sebelumnya melaporkan bahwa kulit buah durian memiliki aktivitas antihiperurisemia pada mencit putih jantan dengan penurunan kadar asam urat sebesar $0,37 \pm 0,25 \mathrm{mg} / \mathrm{dL} .{ }^{13}$ Secara empiris, bagian daun durian dimanfaatkan masyarakat Provinsi Jambi terutama Muaro Jambi sebagai pengobatan sakit pinggang, penurun demam, dan asam urat. Data ilmiah diperlukan untuk membuktikan khasiat daun durian sebagai penurun asam urat. Oleh karena itu, penelitian ini dilakukan untuk menguji efek dari ekstrak etanol daun durian sebagai antihiperurisemia.

\section{METODE PENELITIAN}

Desain penelitian ini adalah eksperimental dengan rancangan penelitian acak lengkap. Kegiatan penelitian yang 
dilakukan adalah pembuatan simplisia dan ekstrak daun durian, identifikasi ekstrak, uji organoleptis, penentuan susut pengeringan dan kadar abu, skrining fitokimia ekstrak daun durian, pembuatan larutan uji, dan uji efektivitas antihiperurisemia.

\section{Alat dan bahan}

Alat yang digunakan antara lain rotary evaporator (Buchi R-114 ${ }^{\circledR}$ ), oven, blender $\left(\right.$ Philips $\left.^{\circledR}\right)$, timbangan analitik $\left(\right.$ Ohause $\left.^{\circledR}\right)$, pengukur asam urat digital (Easy touch $\mathrm{GCU}^{\circledR}$ ), strip asam urat (Easy touch $\left.\mathrm{GCU}^{\circledR}\right)$.

Bahan yang digunakan adalah kalium oksonat $250 \mathrm{mg} / \mathrm{kgBB}\left(\right.$ Sigma $\mathrm{A}^{\circledR}$ ) dengan pelarut $\mathrm{NaCl}$ fisiologis $0,9 \%\left(\mathrm{Ecosol}^{\circledR}\right)$, jus hati ayam, etanol $70 \%$ (Brataco $\left.{ }^{\circledR}\right)$, CMC$\mathrm{Na}$ teknis $0,5 \%$, allopurinol $100 \mathrm{mg} / \mathrm{kgBB}$ (Kimia Farma ${ }^{\circledR}$ ), etanol $96 \%$ teknis $\left(\right.$ Brataco $\left.^{\circledR}\right)$, aquadest, $\mathrm{FeCl}_{3} \quad 1 \% \quad$ PA $\left(\right.$ Merck $\left.^{\circledR}\right), \mathrm{H}_{2} \mathrm{SO}_{4}$ pekat $\mathrm{PA}\left(\mathrm{Merck}^{\circledR}\right), \mathrm{HCl}$ pekat PA $\left(\right.$ Merck $\left.^{\circledR}\right)$, asam asetat anhidrida, serbuk $\mathrm{Mg}$, reagen Dragendorff, reagen Mayer.

\section{Prosedur kerja \\ Pengambilan sampel}

Sampel daun durian ( $D$ zibethinus Linn.) diperoleh dari Kabupaten Batanghari, Kecamatan Pamayung, Kelurahan Selat. Jumlah daun durian yang dibutuhkan pada penelitian ini sebanyak 4 $\mathrm{kg}$ dan pengambilan daun durian dilakukan secara langsung dengan cara pemetikan.

\section{Identifikasi tanaman}

Identifikasi tanaman dilakukan di Herbarium Universitas Andalas Jurusan Biologi FMIPA Universitas Andalas.

\section{Pembuatan serbuk simplisia}

Pembuatan simplisia meliputi tahapan yaitu sortasi basah, pencucian dengan air mengalir, perajangan, pengeringan, pengepakan, dan penggilingan. Serbuk simplisia dibuat dari simplisia utuh atau potongan-potongan halus simplisia yang sudah dikeringkan melalui proses pembuatan serbuk dengan suatu alat tanpa menyebabkan kerusakan atau kehilangan kandungan kimia yang dibutuhkan dan diayak hingga diperoleh serbuk dengan derajat kehalusan tertentu. ${ }^{14}$

\section{Pembuatan ekstrak daun durian}

Pembuatan ekstrak daun durian dilakukan menggunakan serbuk kering simplisia yang selanjutnya dilakukan maserasi dengan pelarut etanol $70 \%$. Ekstrak dibuat dengan memasukkan satu bagian serbuk kering ke dalam maserator, lalu ditambahkan 10 bagian pelarut. Selanjutnya direndam selama 6 jam pertama sambil sesekali diaduk, kemudian didiamkan selama 18 jam. Maserat yang didapat dipisahkan dengan filtrasi. Maserat yang didapat dikumpul dan maserasi lagi sebanyak 2 kali dengan menggunakan pelarut yang sama. Filtrat yang diperoleh dipekatkan dengan menggunakan vacum rotary evaporator pada suhu $50^{\circ} \mathrm{C}$ dengan modifikasi hingga menjadi ekstrak kental. ${ }^{13,14}$

\section{Penentuan parameter nonspesifik}

Susut pengeringan

Ekstrak ditimbang seksama sebanyak 1 $\mathrm{g}$ dengan krus porselen tertutup yang sebelumnya telah dipanaskan pada suhu $105^{\circ} \mathrm{C}$ selama 30 menit dan telah ditara. Ekstrak diratakan dengan menggoyangkan krus porselen, kemudian tutupnya dibuka dan krus dibiarkan dalam keadaan mendingin dalam desikator hingga suhu kamar. Bobot yang diperoleh dicatat untuk menghitung persentase susut pengeringan. ${ }^{15}$

\section{Kadar abu}

Ekstrak ditimbang sebanyak $2 \mathrm{~g}$ dengan seksama ke dalam krus yang telah ditara, kemudian dipijarkan perlahan-lahan dan suhu dinaikkan secara bertahap hingga $600 \pm 25^{\circ} \mathrm{C}$ sampai bebas karbon. Selanjutnya didinginkan dalam desikator dan ditimbang kadar abu dalam persen terhadap berat sampel awal. ${ }^{15}$ 


\section{Parameter spesifik}

Identitas

Identifikasi tata nama meliputi nama latin tumbuhan, bagian tumbuhan yang digunakan, dan nama Indonesia tumbuhan. ${ }^{15}$

Organoleptis

Identifikasi organoleptis menggunakan panca indera dengan mendeskripsikan bau, bentuk, rasa, dan warna. ${ }^{15}$

\section{Skrining fitokimia}

Uji alkaloid

Ekstrak dilarutkan dengan $5 \mathrm{~mL} \mathrm{HCl}$ $2 \mathrm{~N}$. Larutan yang didapat dibagi menjadi 2 tabung reaksi. Tabung pertama ditambahkan pereaksi Dragendorff sebanyak 3 tetes dan tabung kedua ditambah pereaksi Mayer 3 tetes. Terbentuknya endapan jingga pada tabung pertama dan endapan putih hingga kekuningan pada tabung kedua menunjukkan adanya alkaloid. ${ }^{16}$

\section{Uji flavonoid}

Ekstrak dicampur dengan $5 \mathrm{~mL}$ etanol $96 \%$, dikocok, dipanaskan, dan dikocok lagi. Lalu ditambahkan serbuk $\mathrm{Mg} \mathrm{0,2} \mathrm{g}$ dan 3 tetes $\mathrm{HCl} 2 \mathrm{~N}$. Terbentuknya warna merah, kuning, dan orange menunjukkan adanya flavonoid. ${ }^{17}$

\section{Uji steroid}

Ekstrak dilarutkan dalam $0,5 \mathrm{~mL}$ kloroform, ditambahkan dengan $0,5 \mathrm{~mL}$ asam asetat anhidrida. Selanjutnya campuran tersebut ditetesi dengan $2 \mathrm{~mL}$ asam sulfat pekat melalui dinding tabung. Terbentuknya warna hijau kebiruan menunjukkan adanya sterol, sedangkan terbentuknya cincin kecokletan atau violet menunjukkan adanya triterpenoid. ${ }^{16}$

Uji saponin

Ekstrak ditambahkan dengan $10 \mathrm{~mL}$ air panas lalu didinginkan, kemudian dikocok kuat selama 10 detik. Jika terbentuk busa setinggi $1-10 \mathrm{~cm}$ yang stabil tidak kurang dari 10 menit dan tidak hilang dengan penambahan 1 tetes $\mathrm{HCl} 2 \mathrm{~N}$ memberikan indikasi adanya saponin. ${ }^{16}$

Uji fenolik

Sejumlah ekstrak ditambahkan 3-4 tetes larutan besi (III) klorida $\left(\mathrm{FeCl}_{3}\right)$. Terbentuknya warna biru-hitam menunjukkan adanya fenolik. ${ }^{18}$

\section{Uji efektivitas antihiperurisemia}

Pembuatan suspensi CMC-Na 0,5\%

Sebanyak 0,05 g Na-CMC ditaburkan merata ke dalam lumpang yang berisi air panas $1 \mathrm{~mL}$ dan dibiarkan selama 5 menit lalu diaduk sampai homogen. Selanjutnya ditambahkan sampai $10 \mathrm{~mL}$ air panas dan digerus sampai homogen. ${ }^{19}$

Pembuatan jus hati ayam

Hati ayam ditimbang sebanyak $37 \mathrm{~g}$ dan ditambahkan air sebanyak $5 \mathrm{ml}$, kemudian hati ayam dihaluskan menggunakan blender sampai halus sekitar 15 menit. Volume pemberian hati ayam pada mencit adalah $0,2 \mathrm{~mL} / 20 \mathrm{gBB}^{20}$

Pembuatan kalium oksonat

Kalium oksonat digunakan sebagai penginduksi hiperurisemia dengan dosis $250 \mathrm{mg} / \mathrm{kgBB}$. Kalium oksonat ditimbang sebanyak $325 \mathrm{~g}$ dan dimasukkan ke dalam beaker glass $50 \mathrm{~mL}$, kemudian ditambahkan $\mathrm{NaCl} \quad 0,9 \%$ sebanyak 13 $\mathrm{mL}^{21}$

Pembuatan suspensi allopurinol

Dosis yang diberikan pada hewan uji adalah $10 \mathrm{mg} / \mathrm{kgBB}$. Allopurinol digunakan sebagai kontrol positif. Pembuatan allopurinol dilakukan dengan cara menimbang sebanyak $0,024 \mathrm{~g}$, lalu disuspensikan dalam $10 \mathrm{~mL}$ larutan CMC $\mathrm{Na} 0,5 \%$, kemudian aduk sampai homogen. $^{22}$

Pembuatan suspensi ekstrak etanol daun

Ekstrak etanol daun durian ditimbang dengan dosis $50 \mathrm{mg} / \mathrm{kgBB}, 100 \mathrm{mg} / \mathrm{kgBB}$, $200 \mathrm{mg} / \mathrm{kgBB}$, dan $250 \mathrm{mg} / \mathrm{kgBB}$. Masingmasing dimasukkan ke dalam lumpang dan ditambahkan CMC-Na 0,5\% sebanyak 10 
$\mathrm{mL}$ tiap masing-masing dosis ekstrak dan digerus sampai homogen. ${ }^{23}$

\section{Perlakuan hewan uji}

Hewan uji dibagi secara acak lengkap dalam 6 kelompok. Semua kelompok diberikan induksi kalium oksonat 250 $\mathrm{mg} / \mathrm{kgBB}$ dan jus hati ayam $0,2 \mathrm{~mL} / 20$ gBB selama enam hari. Kelompok I adalah kontrol negatif dimana mencit diberikan suspensi Na-CMC 0,5\%, kelompok II adalah kontrol positif, yaitu mencit yang diberikan suspensi allopurinol 10 mg/kgBB. Kelompok III, IV, V, dan VI adalah kelompok yang diberikan dosis ekstrak etanol daun durian masing-masing 50, 100, 200, dan $250 \mathrm{mg} / \mathrm{kgBB}$.

Pengukuran kadar asam urat

Pengukuran kadar asam urat dilakukan dengan sedikit modifikasi dari metode yang digunakan oleh Amir (2018). ${ }^{24} \mathrm{Uji}$ efektivitas antihiperurisemia menggunakan metode POCT dengan sampel yang diperoleh dari vena lateralis ekor mencit sepanjang $\quad 0,1-0,3 \quad \mathrm{~cm}$. Mencit diaklimatisasi terlebih dahulu selama tujuh hari sebelum dilakukan percobaan. Selanjutnya mencit dipuasakan selama 1016 jam. Kemudian pada hari ke-0 (H-0) tiap kelompok perlakuan diukur kadar asam urat awal dengan meneteskan darah yang berasal dari vena lateralis ekor mencit pada test strip dan darah akan langsung meresap sampai ujung strip dalam waktu 20 detik. $^{24}$

Pada hari selanjutnya (hari ke-1 sampai hari ke-6), mencit diberikan larutan kalium oksonat $250 \mathrm{mg} / \mathrm{kgBB}$ satu kali sehari dan jus hati ayam $0,2 \mathrm{~mL} / 20 \mathrm{gBB}$ dua kali sehari (pagi dan sore) secara per oral selama enam hari. Pada hari ke-6 (H-6), satu jam setelah pemberian induksi, diukur kadar asam urat mencit tiap kelompok. Pada hari ke-7 sampai hari ke-15 (setiap hari selama sembilan hari) dilakukan pemberian perlakuan berdasarkan kelompoknya. Pada hari ke-15 (H-15) diukur kadar asam urat pada setiap kelompok setelah satu jam pemberian perlakuan. ${ }^{24}$
Perhitungan persentase penurunan kadar asam urat darah :

Penurunan $=\frac{\text { Kadar pada saat Hiperurisemia }- \text { Kadar Sampel }(\text { Hari })}{\text { Kadar pada saat Hiperurisemia }- \text { Kadar Normal }} \times 100 \%$

\section{Analisis data}

Kandungan metabolit sekunder pada ekstrak daun durian diamati secara deskriptif. Data hasil penelitian dilakukan uji normalitas data (One-Sample Kolmogorov-Smirnov Test) terlebih dahulu untuk melihat homogenitas dari data. Apabila diperoleh nilai $\mathrm{P}>0,05$ maka pengujian dilanjutkan dengan uji parametrik One Way Anova terhadap nilai kadar asam urat yang diperoleh dan dilanjutkan uji lanjut Duncan untuk menentukan perbedaan rata-rata di antara dan untuk melihat perbedaan antarperlakuan.

\section{HASIL DAN PEMBAHASAN}

\section{Parameter Nonspesifik}

Parameter nonspesifik yang dilakukan pada penelitian ini meliputi susut pengeringan dan kadar abu. Berdasarkan hasil yang diperoleh (Tabel 1), susut pengeringan ekstrak etanol daun durian adalah $2,55 \%$. Hal ini menunjukkan bahwa kadar air yang terkandung dalam ekstrak rendah sehingga memenuhi standar Farmakope Herbal Indonesia yaitu nilai susut pengeringan ekstrak tidak lebih dari $10 \% .{ }^{14}$ Susut pengeringan kulit buah durian dilaporkan lebih besar, yaitu $4 \% .^{25}$

\section{Tabel 1. Parameter nonspesifik daun durian}

\begin{tabular}{lc}
\hline Parameter & $\begin{array}{c}\text { Hasil analisa } \\
(\boldsymbol{\%})\end{array}$ \\
\hline Susut pengeringan & 2,55 \\
Kadar abu & 3,83 \\
\hline
\end{tabular}

Kadar abu total pada ekstrak etanol daun durian sebesar 3,83\%. Hasil ini sesuai dengan standar Farmakope Herbal Indonesia, yaitu nilai kadar abu total tidak lebih dari $9,0 \%$ untuk rimpang bengle. ${ }^{14}$ Sedangkan pada penelitian sebelumnya nilai kadar abu total dari daun durian adalah $8,4 \%{ }^{26}$ 


\section{Parameter spesifik}

Identitas dan organoleptis

Tujuan pemeriksaan identitas dan organoleptis ekstrak adalah untuk memberikan identitas objektif seperti nama, bentuk, warna, rasa dan bau. ${ }^{15}$ Hasil identitas dan organoleptis ekstrak daun durian dapat ditunjukkan pada Tabel 2.

Tabel 2. Identitas dan organoleptis ekstrak daun durian

\begin{tabular}{|c|c|}
\hline Parameter & Hasil \\
\hline \multicolumn{2}{|l|}{ Identitas ekstrak } \\
\hline Nama ekstrak & $D$ zibethinus \\
\hline Nama latin tumbuhan & extractum \\
\hline Nama Indonesia & $D$ zibethinus Linn. \\
\hline $\begin{array}{l}\text { Bagian tumbuhan yang } \\
\text { digunakan }\end{array}$ & $\begin{array}{l}\text { Durian } \\
\text { Daun }\end{array}$ \\
\hline \multicolumn{2}{|l|}{ Organoleptis ekstrak } \\
\hline Bentuk & Ekstrak kental \\
\hline Warna & Hijau kecoklatan \\
\hline Rasa & Pahit (sepet) \\
\hline Bau & Khas ekstrak \\
\hline
\end{tabular}

Kandungan metabolit sekunder

Analisis senyawa metabolit sekunder yang dilakukan meliputi alkaloid, flavonoid, steroid, saponin, dan fenolik. Berdasarkan hasil skrining fitokimia (Tabel 3) ekstrak daun durian mengandung senyawa metabolit sekunder, yaitu flavonoid, steroid, saponin, dan fenolik. Menurut penelitian sebelumnya di dalam ekstrak daun durian tidak mengandung senyawa alkaloid. Senyawa metabolit sekunder flavonoid dan fenolik yang terkandung di dalam daun durian dapat menghambat aktivitas dari xantin oksidase dan superoksidase sehingga dapat mengurangi pembentukan asam urat di dalam darah yang akan memicu terjadinya hiperurisemia. ${ }^{27,28}$

Tabel 3. Kandungan metabolit sekunder ekstrak daun durian dari hasil skrining fitokimia

\begin{tabular}{lc}
\hline Skrining fitokimia & Hasil \\
\hline Alkaloid & - \\
Flavonoid & + \\
Steroid & + \\
Saponin & + \\
Fenolik & + \\
\hline
\end{tabular}

Keterangan: $(+)=$ ada kandungan,$(-)=$ tidak ada kandungan

\section{Uji efektivitas antihiperurisemia}

Kandungan metabolit sekunder pada ekstrak etanol daun durian seperti flavonoid dan fenolik diduga mampu menurunkan kadar asam urat pada mencit putih jantan. Pada penelitian ini dilakukan pengukuran kadar asam urat awal sebelum induksi, setelah induksi, dan setelah pemberian perlakuan pada masing-masing kelompok hewan uji. Hasil yang diperoleh menunjukkan efektivitas penurunan kadar asam urat pada mencit yang hiperurisemia (Tabel 4).

Berdasarkan hasil analisis statistik normalitas kadar asam urat pada mencit menunjukkan bahwa data yang diperoleh adalah homogen $(\mathrm{P}>0,05)$. Selanjutnya dilakukan pengujian One Way ANOVA versi 21 yang menunjukkan bahwa kadar asam urat total pada hari ke-0 (H-0) tidak ada perbedaan yang signifikan antarkelompok perlakuan $(\mathrm{P}>0,05)$.

Tabel 4. Rata-rata kadar asam urat total darah mencit

\begin{tabular}{ccccc}
\hline \multirow{2}{*}{ Perlakuan } & \multicolumn{3}{c}{ Rata-rata kadar asam urat (mg/dL) \pm SEM } & Persentase penurunan kadar asam \\
\cline { 2 - 4 } & H-0 & H-6 & H-15 & 44,46 \\
\hline K+ & $3,056^{\mathrm{A}} \pm 0,0377$ & $6,422^{\mathrm{A}} \pm 0,1256$ & $3,567^{\mathrm{A}} \pm 0,0986$ & $-12,89$ \\
$\mathrm{~K}-$ & $3,122^{\mathrm{A}} \pm 0,0324$ & $6,289^{\mathrm{A}} \pm 0,1467$ & $7,100^{\mathrm{C}} \pm 0,1374$ & 38,68 \\
$\mathrm{P} 1$ & $3,022^{\mathrm{A}} \pm 0,0278$ & $6,289^{\mathrm{A}} \pm 0,1317$ & $3,856^{\mathrm{A}} \pm 0,1119$ & 40,53 \\
P2 & $3,089^{\mathrm{A}} \pm 0,0351$ & $6,278^{\mathrm{A}} \pm 0,1222$ & $3,733^{\mathrm{A}} \pm 0,0986$ & 27,71 \\
P3 & $3,022^{\mathrm{A}} \pm 0,0364$ & $6,256^{\mathrm{A}} \pm 0,1144$ & $4,522^{\mathrm{B}} \pm 0,0909$ & 22,36 \\
P4 & $3,044^{\mathrm{A}} \pm 0,0338$ & $6,111^{\mathrm{A}} \pm 0,1285$ & $4,744^{\mathrm{B}} \pm 0,1082$ & \\
\hline
\end{tabular}

Keterangan: Superskrip dengan huruf besar yang berbeda pada kolom yang sama menunjukkan perbedaan yang nyata $(\mathrm{P}<0,05)$. K- (CMC-Na 0,5\%), K+ (allopurinol $10 \mathrm{mg} / \mathrm{kgBB}), \mathrm{P} 1$ (ekstrak etanol daun durian dosis 50 $\mathrm{mg} / \mathrm{kgBB}$ ), P2 (ekstrak etanol daun durian dosis $100 \mathrm{mg} / \mathrm{kgBB}$ ), P3 (ekstrak etanol daun durian dosis 200 $\mathrm{mg} / \mathrm{kgBB}$ ) dan P4 (ekstrak etanol daun durian dosis $250 \mathrm{mg} / \mathrm{kgBB}$ ). SEM : Standar Error Mean. 
Hal ini menunjukkan hewan uji yang digunakan dalam kondisi yang sama, yaitu memiliki kadar asam urat yang normal. Nilai kadar asam urat mencit sebelum diberikan perlakuan apapun pada hari ke-0 setelah mencit dipuasakan adalah antara 1,5-3,3 mg/dL. ${ }^{29}$ Pengambilan darah awal (H-0) pada mencit jantan Swiss Webstar sebelum diberikan perlakuan apapun pada penelitian ini memiliki kadar asam urat dengan nilai rata-rata $3,0 \mathrm{mg} / \mathrm{dL}$. Hasil yang didapat pada pengukuran kadar asam urat awal (H-0) mencit. Tingginya kadar asam urat mencit dapat dipengaruhi oleh beberapa faktor, yaitu jenis mencit yang digunakan dan pakan standar yang dikonsumsi selama aklimatisasi. Pakan yang mengandung protein tinggi (minimun $15 \%$ ) dapat meningkatkan kadar asam urat mencit. Komposisi pakan hewan uji yang digunakan sebagai antihiperurisemia lebih disarankan mengandung protein yang rendah yaitu maksimum $10 \%$ sesuai dengan standar pakan menurut Association of Official Analytical Chemists (AOAC) $1990 . .^{30}$

Pengambilan darah hari ke-6 (H-6) pada mencit menunjukan bahwa tidak ada perbedaan yang signifikan antar kelompok perlakuan $(\mathrm{P}>0,05)$. Hal ini disebabkan hewan uji yang digunakan dalam kondisi yang sama dan tidak mengalami stres selama penginduksian sehingga setiap kelompok hewan uji mengalami kondisi hiperurisemia. Kadar rata-rata asam urat mencit setelah penginduksian adalah 6,2 $\mathrm{mg} / \mathrm{dL}$, nilai ini menunjukkan mencit sudah mengalami hiperurisemia. Mencit dikatakan hiperurisemia jika kadar asam urat mencapai 6,2-7,1 mg/dL. ${ }^{31}$

Pengambilan darah pada hari ke-15 (H15) menunjukkan bahwa pemberian ekstrak etanol daun durian dan allopurinol berbeda signifikan $(\mathrm{P}<0,05)$ terhadap kadar asam urat total mencit. Uji lanjut (Post Hoc Duncan) menunjukkan bahwa rata-rata kadar asam urat total darah mencit pada kelompok perlakuan P1, P2, P3, P4, dan K+ nyata $(\mathrm{P}<0,05)$ lebih rendah dari kelompok kontrol negatif $(\mathrm{K}-)$. Kelompok P1 dan P2 berbeda tidak nyata $(\mathrm{P}>0,05)$ dibanding dengan kontrol positif $(\mathrm{K}+)$.

Persentase penurunan tertinggi terdapat pada kelompok P2 (100 $\mathrm{mg} / \mathrm{kgBB}$ ) dengan penurunan kadar asam urat mencit sebesar $40,53 \%$ yang hampir mendekati kelompok $\mathrm{K}+$ (allopurinol 10 $\mathrm{mg} / \mathrm{kgBB}$ ) yaitu $44,46 \%$. Allopurinol digunakan sebagai pembanding atau kontrol positif untuk mengetahui seberapa besar kemampuan allopurinol dalam menghambat kerja enzim xantin oksidase dalam menurunkan kadar asam urat. ${ }^{28}$ Kemudian penurunan kadar asam urat mencit pada ekstrak etanol daun durian diikuti pada kelompok P1 $(50 \mathrm{mg} / \mathrm{kgBB})$ sebesar $38,68 \%$. Penurunan kadar asam urat mencit yang paling lemah terdapat pada kelompok P4 (250 $\mathrm{mg} / \mathrm{kgBB})$ dengan persentase penurunanya adalah 23,36\% dan diikuti dengan kelompok P3 (200 mg/kgBB) sebesar 27,71\%.

Peningkatan dosis obat seharusnya akan meningkatkan respon yang sebanding dengan dosis yang ditingkatkan. Namun dengan meningkatnya dosis, peningkatan respon pada akhirnya akan menurun karena sudah mencapai dosis yang optimum. Hal tersebut sering terjadi pada penggunaan obat bahan alam karena komponen senyawa tidak tunggal melainkan terdiri dari berbagai macam senyawa kimia yang saling bekerja sama untuk menimbulkan efek yang baik dalam menurunkan kadar asam urat. Namun dengan adanya peningkatan dosis, jumlah senyawa kimia yang dikandung semakin banyak sehingga terjadi interaksi yang merugikan yang dapat menurunkan efektivitas obat. ${ }^{4,11}$

Nilai ED50 dihitung dengan menggunakan regresi linier antara log dosis dan persen penurunan kadar asam urat darah (Gambar 1). Berdasarkan kurva antara log dosis dan persen penurunan kadar asam urat, maka diperoleh persamaan linear yaitu $y=-45,61 x+131,93$ dengan nilai $\mathrm{R}^{2}=0,995$. 


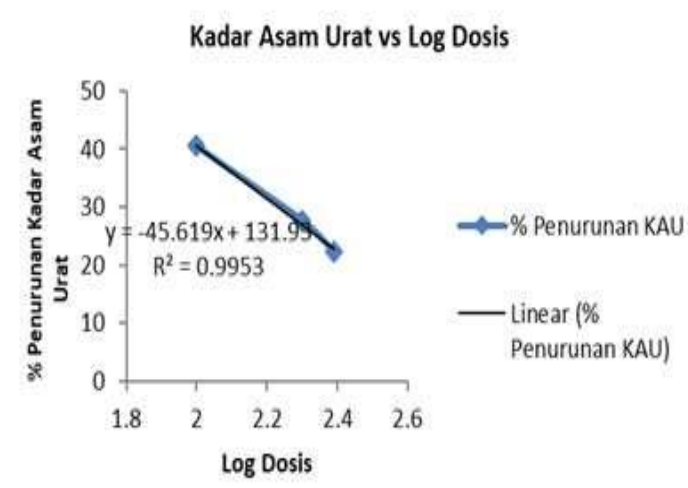

Gambar 1. Kurva hubungan antara log dosis dan persentase penurunan kadar asam urat

Variasi dosis yang digunakan dalam menentukan nilai $\mathrm{ED}_{50}$ pada penelitian ini adalah dosis ekstrak etanol daun durian 100 $\mathrm{mg} / \mathrm{kgBB}, 200 \mathrm{mg} / \mathrm{kgBB}, 250 \mathrm{mg} / \mathrm{kgBB}$. Nilai $E_{50}$ yang diperoleh dari ekstrak etanol daun durian tersebut sebesar 61,65 $\mathrm{mg} / \mathrm{kgBB}$. Artinya bahwa dengan pemberian ekstrak etanol daun durian pada dosis $61,65 \mathrm{mg} / \mathrm{kgBB}$ mampu menurunkan $50 \%$ kadar asam urat pada mencit yang hiperurisemia.

Senyawa metabolit sekunder yang sangat berperan dalam menurunkan kadar asam urat adalah senyawa flavonoid. Golongan senyawa aktif dari flavonoid dapat menghambat aktivitas dari xantin oksidase dan superoksidase sehingga dapat mengurangi pembentukan asam urat di dalam darah yang akan memicu terjadinya antihiperurisemia. $^{28}$ Hiperurisemia terjadi karena akumulasi asam urat dalam tubuh yang akan menyebabkan kadar purin dalam tubuh menjadi asam urat endogen oleh xantin oksidase. ${ }^{32}$

Selain itu, senyawa fenolik juga berpotensi dalam menurunkan resiko gout yang terjadi akibat timbunan kristal monosodium urat (MSU) yang meningkat. Timbunan kristal tersebut akan menyebabkan peradangan atau inflamasi jaringan yang memicu timbulnya reumatik. Keadaan ini terjadi karena adanya peningkatan kadar asam urat di atas nilai normal (hiperurisemia). Jika tidak diobati akan menyebabkan kerusakan hebat pada sendi dan jaringan lunak. ${ }^{33}$

\section{KESIMPULAN}

Ekstrak etanol daun durian berpengaruh secara signifikan terhadap penurunan kadar asam urat total pada mencit dengan nilai inhibisi $\mathrm{ED}_{50}$ terdapat pada dosis $61,65 \mathrm{mg} / \mathrm{kgBB}$ dan memiliki potensi sebagai obat antihiperurisemia.

\section{SARAN}

Penelitian lebih lanjut diperlukan untuk mengetahui dan memperoleh isolat senyawa dari daun durian yang berpotensi sebagai antihiperurisemia serta penilaian keamanan ekstrak melalui uji toksisitas akut dan subkronis.

\section{DAFTAR RUJUKAN}

1. Sari RP, Ariani N, Febrianti DR. Uji aktivitas antihiperurisemia ekstrak etanol Semut Jepang (Tenebrio molitor L) pada tikus putih jantan galur Spague-Dawley. Cahaya N, Anwar K, editor. Pendidikan farmasi dan apoteker yang paripurna untuk mencapai kompetensi dalam menghadapi persaingan global. Prosiding Seminar Nasional Asosiasi Pendidikan Tinggi Farmasi Indonesia (APTFI) II; 2017 Nov 16-18; Banjarmasin, Indonesia. Banjarmasin: Program Studi Farmasi Fakultas Matematika dan Ilmu Pengetahuan Alam Universitas Lambung Mangkurat; 2017. p. 107-12.

2. Wells BG, DiPiro JT, Schwinghammer TL, DiPiro CV, editors. Pharmacotherapy handbook. $9^{\text {th }}$ ed. New York: Mc GrawHill; 2015.

3. Pokharel K, Yadav BK, Jha B, Parajuli K, Pokharel RK. Estimation of serum acid in cases of hyperuricaemia and gout. Journal Nepal Medicinal Association. 2015;51(181):15-20.

4. Katzung BG, Masters SB, Trevor AJ. Ricky Soehars, editor. Farmakologi dasar dan klinik. Edisi 12 volume 1. Jakarta: EGC; 2012.

5. Kusuma AM, Wahyuningrum R, Widyati T. Aktivitas antihiperurisemia ekstrak etanol herba pegagan pada mencit jantan dengan induksi kafein. Pharmacy. 2014;11(01):62-74.

6. BPTP Balitbangtan Sulawesi Barat. Durian si raja buah kontroversial 
[Internet]. BPTP Balitbangtan Sulawesi Barat; 2020 [disitasi 2020 Feb 01]. Diunduh dari: http://sulbar.litbang.pertanian.go.id/ind/ind ex.php/info-teknologi/360-durian-si-rajabuah-kontroversial

7. Maradona D. Uji Aktivitas Antibakteri Ekstrak etanol daun durian (Durio zibenthinus), daun lengkeng (Dimocarpus longan), dan daun rambutan (Nephelium lappaceum) terhadap bakteri Staphylococcus aureus ATCC 25925 dan Escherichia coli ATCC 25922 [skripsi]. Jakarta: UIN Syarif Hidayatullah; 2013.

8. Aruan DGR, Barus T, Haro G, Siburian R, Simanjuntak P. Phytochemical screening and antidiabetic of n-hexane, ethyl acetate, and water extract from durian leaves (Durio zibethinus L.). Oriental Journal of Chemistry. 2019 Jan;35(1):487-90. doi: http://dx.doi.org/10.13005/ojc/350166

9. Basma AA, Zakaria Z, Latha LY, Sasidharan S. Antioxidant Activity and Phytochemical screening of the methanol extracts of Euphorbia hirta L. Asian Pasific Journal of Tropical Medicine. 2011 May;4(5):386-90. doi: 10.1016/S19957645(11)60109-0

10. Xu F, Zhao X, Yang L, Wang X, Zhao J. A new cycloartane-type triterpenoid saponin xanthine oxidase inhibitor from Homonoia riparia Lour. Molecules. 2014 Aug;19(9):13422-31. doi: 10.3390/molecules190913422

11. Pertamawati, Hardhiyuna M. Uji penghambatan aktivitas enzim xantin oksidase terhadap ekstrak kulit kayu secang (Caesalpinia sapan L.). KartikaJurnal Ilmiah Farmasi. 2015 Des;3(2):127. http://dx.doi.org/10.26874/kjif.v3i2.99

12. Suryadinata RV. Pengaruh radikal bebas terhadap proses inflamasi pada penyakit paru obstruktif kronis (PPOK). Amerta Nutrition. 2018 Des;317-24. doi: 10.2473/amnt.v2i4.2018.317-324

13. Muhtadi, NM Sari, Haryoto, Sujono TA, Suhendi A. Aktivitas antihiperurisemia ekstrak etanol kulit buah durian (Durio zibenthinus) dan biji buah kelengkeng (Euphorbia longan). Prosiding Simposium Penelitian Bahan Obat Alami [SPBOA] XVI \& MUKTAMAR XII PERHIPBA. 2014 April;440-7. Solo, Indonesia. Yogyakarta: Leutikaprio.
14. Farmakope Herbal Indonesia. Edisi II. Jakarta: Kementerian Kesehatan Republik Indonesia; 2017.

15. Parameter Standar Umum Ekstrak Tumbuhan Obat. Jakarta: Departemen Kesehatan Republik Indonesia; 2000.

16. Teanpaisan R, Kawsud P, Pahumunto N, Puripattanavong J. Screening for antibacterial and antibiofilm activity in Thai medicinal plant extract against oral microorganisms. Journal of Traditional and Complementary Medicine. 2017 Apr;7(2):172-7.

17. Latifah. Identifikasi golongan senyawa flavonoid dan uji aktivitas antioksidan pada ekstrak rimpang kencur (Kaempferia galangal L.) dengan metode DPPH (1,1-Difenil-2-Pikrilhidrazil) [skripsi]. Malang; 2015.

18. Tiwari P, Kumar B, Kaur M, Kaur G, Kaur H. Phytochemical screening and extraction: a review. International Pharmaceutica Sciencia. 2011;1(1):98106.

19. Masruroh IK. Uji aktivitas antihiperurisemia ekstrak metanol biji juwet (Syzygium cumini (L) Skeels.) pada mencit jantan galur Balb-C hiperurisemia [skripsi]. Jember: Universitas Jember; 2016.

20. Cendrianti F, Muslichah S, Ulfa EU. Uji aktivitas antihiperurisemia ekstrak nheksana, etil asetat, dan etanol $70 \%$ daun tempuyung (Sonchus arvensis L.) pada mencit jantan hiperurisemia. e-Jurnal Pustaka Kesehatan. 2014 Mei;2(2):20510.

21. Jiang $\mathrm{Y}$, Lin $\mathrm{Y}, \mathrm{Hu} \mathrm{YJ}$, Song $\mathrm{XJ}$, Pan $\mathrm{HH}$, Zhang HJ. Caffeoylquinic acid derivates rich extract from Gnaphalium Pensylvanicum Wild. Ameliorates hyperuricemia and acute gouty arthritis in animal model. BMC Complementary and alternative medicine. 2017 Jun;17(1):320. doi: 10.1186/s12906-017-1834-9

22. Suhendi A, Nurcahyanti, Muhtadi, Sutrisna EM. Aktivitas antihiperurisemia ekstrak air jinten hitam (Coleus ambonicus Lour.) pada mencit jantan galur Balb-C dan standarisasinya. Majalah Farmasi Indonesia. 2011;22(2):77-84.

23. Ardiyanti R. Efek Antihiperurisemia Ekstrak etanol herba pugun tanoh (Picria fel-terrae Lour.) terhadap tikus jantan 
[skripsi]. Medan: Universitas Sumatera Utara; 2018.

24. Amir M, Purukan JIA. Uji efektivitas ekstrak etanol buah naga putih (Hylocereus undatus) terhadap penurunan kadar asam urat darah pada mencit (Mus musculus). Jurnal Ilmu Kefarmasian Indonesia. 2018;16(2):166-71.

25. Saputra RA, Mulkiya K, Dasuki UA. Pengaruh metode ekstraksi refluks dan ekstraksi sinambung terhadap aktivitas antioksidan dan penetapan total fenol dan flavonoid dari kulit buah durian (Durio zibethinus Murray). Prosiding Farmasi. 2017;3(1):85-92.

26. Insanu M, Ruslan K, Fidrianny I, Wijaya S. Isolasi flavonoid dari daun durian (Durio zibethinus Murr. Bombacaceae). Acta Pharmaceutica Indonesia. 2011; 36(1\&2):6-10.

27. Ang AMG, Nalda CMDR, Sabejon SE. Brine shrimp lethality and antioxidant activity of the leaf, rind and seed ethanolic extracts of Durio zibethinus L. Asian Journal of Biological and Life Sciences. 2018;7(3):105-11.

28. Wadjie F, Kartika R, Saleh C. Uji Aktivitas antihiperurisemia dari ekstrak etanol daun kluwih (Artocarpus altilis (Parkinson) Fosberg.) terhadap mencit jantan (Mus musculus). Jurnal Atomik. 2018;3(2):111-5.

29. Hidayah $N$, Hasanah $F$, Gunawan $M$, Lestari A. Uji efektivitas antihiperurisemia ekstrak air daun salam (Syzygium polyanthum Wight.) terhadap mencit jantan (Mus musculus) yang di induksi jus hati ayam dan kalium oksonat. Jurnal PenelitianSaintika. 2018;18(1):24-31.

30. Rizki, KP, Muslichah S, Ningsih IY. Pengaruh pemberian kombinasi ekstrak etanol daun sidaguri (Sida rhombifolia L.) dan rimpang jahe merah (Zingiber officinale Rosc.) pada mencit jantan hiperurisemia. e-jurnal Pustaka Kesehatan. 2018;6(2):205-11

31. Juwita R, Saleh C, Sitorus S. Uji aktivitas antihiperurisemia dari daun hijau tanaman pucuk merah (Syzygium myrtifolium Walp.) terhadap mencit jantan (Mus musculus). Jurnal Atomik. 2017;2(1):1628.

32. Saigal R, Agrawal A. Pathogenesis and clinical management of gouty arthritis. Journal of the Association of Physicians of India. 2016;63(12):56-63.
33. Ningtiyas IF, Ramadhian MR. Efektivitas ekstrak etanol daun salam untuk menurunkan kadar asam urat pada penderita artritis gout. Majority. 2016;5(3):105-10. 